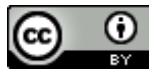

\title{
COLOMBO SUBURBAN RAILWAY PROJECT: REVIEW OF THE FEASIBILITY STUDY AND PROPOSAL FOR THE WAY FORWARD
}

\section{Tilak Siyambalapitiya}

Managing Director, Resource Management Associates (Pvt) Ltd, and

Former Chief Engineer (Planning), Ceylon Electricity Board, Sri Lanka

\section{INTRODUCTION}

Upgrading the railway network for faster travel, modern rolling stock and passenger facilities is a long-felt need. The Government made a policy decision in 2015 to upgrade and electrify the network serving the suburbs of Colombo, and a project by the name "Colombo Suburban Railway Project (CSRP)" was established in 2016 under the Ministry of Transport. By way of the existing network, the logical nodes of CSRP may be identified as Colombo-Polgahawela (main line), Colombo-Kalutara South (coastal line), Colombo-Avissawella (Kelani valley line) and Ragama-AirportNegombo (Puttalam line). The distant nodes approximately reflect the boundaries of the Western Province.

CSRP published feasibility study reports in 2019 (for Kelani Valley line [1]) and in 2020, for main, coastal and Puttalam lines [2]. The reports are available in the public domain, and CSRP from time to time, invited public comments on their contents. However, there are no reports of any public comments being accommodated or revisions being made to CSRP designs.

Figure 1 shows the layout of the Colombo Suburban Railway Project as it is conceptualised at present (2021) by the Ministry of Transport. CSRP defines Rambukkana (on the Main Line), Kalutara south (on the Coastal Line), Negombo (on the Puttalam Line) and Avissawella (on the KV Line) as the end nodes of the suburban railway network of Colombo. 


\section{Figure 1: Colombo Suburban Railway Network Proposed to be Upgraded and Electrified}

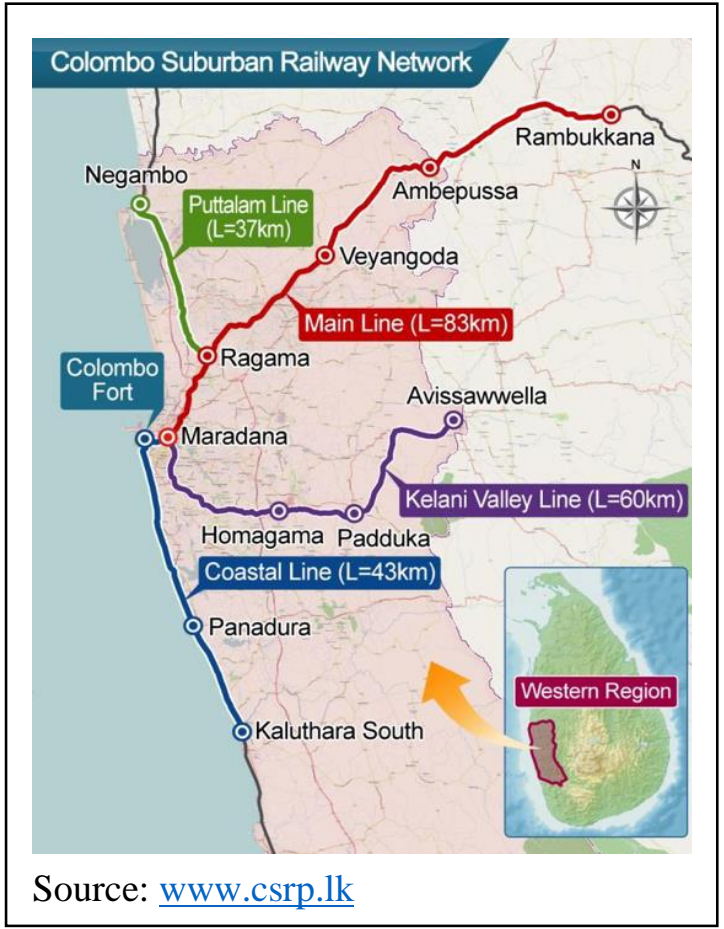

The Light Rail Transit (LRT) project, widely in discussion since 2015 plans to build four lines, mostly elevated, exclusively for passenger transport, serving the immediate suburbs of Colombo. In contrast, CSRP specifically addresses the long-felt need to improve the efficiency of the existing railway network, using - to a large extent - the existing right of way. The LRT requires a passenger market to be developed, whereas CSRP already has no less than 200,000 passenger trips per day within the CSRP zone and offers added benefits to longer distance passengers passing through the suburban sectors.

Railway investments are typically not financially viable: there cannot be a viable business that makes profits by building railway infrastructure, purchasing rolling stock and operating a passenger service. However, just as any other public investment, they should be economically viable: for example, building CSRP may not make Sri Lanka Railways a profitable entity but CSRP should bring in adequate economic value to the country by way of fuel saved (diesel replaced with electricity, and overall technical and commercial efficiency), avoided investments on roads and vehicles, and faster travel times. If economic benefits too are uncertain or inadequate, then such a project should be redesigned to make it economically viable or should otherwise be abandoned.

This paper reviews the coverage, content, basic accuracy and conclusions of the four feasibility study reports of four sectors of CSRP. The publication of the feasibility study reports was preceded by several other related studies: A Proposal for Railway Electrification, 2008, by the Institution of Engineers, Sri Lanka [3]; KV line alternatives study, 2017[4] by CSRP, and Panadura-Veyangoda Initial Feasibility Report, 2018 [5] by CSRP. The paper also summarises the design features as proposed by the consultants to the Ministry of Transport as of end 2020. It explains the required improvements to the design, costing and economic evaluation, to ensure the planned investments yield the expected economic benefits, without becoming yet 
another liability on the already-constrained national economy. Design features are discussed for each of the four lines, whereas costing and economic evaluation are discussed in overall consideration for all lines. Finally, the paper presents a feasible action plan for more rigorous study and costing to ensure the project makes economic sense.

\section{WHICH LINE FIRST?}

The preliminary study in 2008 by IESL [4], identified the Panadura-ColomboVeyangoda as the sectors to be electrified first. This was on the basis that $43 \%$ of all trips on the entire railway network originated and terminated between Panadura and Veyangoda. Resumption of services to Kankesanthurai and Thalaimannar in 2012 may have slightly lowered this ratio. Using a simplified scoring system, the study compared Panadura-Veyangoda, Kalutara South-Veyangoda and Colombo FortPolgahawela in terms of their relative merits and recommended that PanaduraVeyangoda be prioritised. The study therefore focused on serving existing passengers to be the highest priority. This strategy involves the least uncertainty in terms of forecast passenger numbers and financial/economic benefits. Considering that railway electrification is a relatively new concept in Sri Lanka (although widely and successfully used all over the world), the study recommended a sector of shorter length, proven passenger patronage, a higher passenger share and a higher passenger density, to be electrified first. This was to demonstrate the feasibility of the technological improvements and to gather public support, which is essential for an infrastructure project to serve a large number of people, using public funds.

\section{Table 1: Ranking of Possible Sectors to be Electrified}

\begin{tabular}{|c|c|c|c|c|c|c|c|c|c|}
\hline & $\begin{array}{c}\text { Sector } \\
\text { Starts }\end{array}$ & Sector Ends & $\begin{array}{c}\text { Sector } \\
\text { length } \\
(\mathrm{km})\end{array}$ & $\begin{array}{c}\% \text { of } \\
\text { psgrs } \\
\text { served }\end{array}$ & $\begin{array}{c}\text { Psgrs per } \\
\text { month per } \\
\mathrm{km}\end{array}$ & $\begin{array}{c}\text { Rank in } \\
\text { Distance }\end{array}$ & $\begin{array}{c}\text { Rank in } \\
\text { Passenger } \\
\text { share }\end{array}$ & $\begin{array}{c}\text { Rank in } \\
\text { Passenger } \\
\text { density }\end{array}$ & Sum \\
\hline 1 & Panadura & Veyangoda & 63.4 & $43 \%$ & 58,233 & 3 & 2 & 3 & 8 \\
\hline 2 & $\begin{array}{c}\text { Kalutara } \\
\text { South }\end{array}$ & Veyangoda & 79.0 & $48 \%$ & 52,430 & 1 & 3 & 2 & 6 \\
\hline 6 & Fort & Polgahawela & 73.8 & $39 \%$ & 45,462 & 2 & 1 & 1 & 4 \\
\hline
\end{tabular}

Source: A Proposal for Railway Electrification, The Institution of Engineers, Sri Lanka, June 2008 [4] 
Table 1 above summarises the perception at that time. Equal weighting factors were given for the three criteria (a) distance (longest $=1$, shortest $=3$ ), (b) share of passengers served (lowest=1, highest=3) and (c) passenger density (lowest=1, highest=3)

EGIS, the consultants to the Ministry of Transport, in the pre-feasibility study on the development of Panadura-Veyangoda [5], confirmed the following:

(i) the internal passenger trips within the section is $50 \%$ of the total passenger trips in Sri Lanka Railway,

(ii) the total passengers using the Panadura-Veyangoda corridor (including long distance passengers and transfers from other lines) amounted to 309,400 per day in 2016 , representing $89 \%$ of the total railway passenger trip count of 371,800 .

These two features present a strong case to suggest that the Panadura-Veyangoda sector should be the first to be upgraded and electrified, subject to financial and economic justification.

In contrast, the Final Feasibility Reports of main, coastal, KV and Puttalam lines have worked out forecast passengers for each line. Forecasts were reported for milestone years 2025 and 2035 .

Table 2 shows the passenger data for 2016 (ie at the time feasibility studies commenced) and the forecasts presented in the feasibility studies conducted by consultants to the Ministry of Transport.

Analysis of actual and forecast information reveals the following important features:

(a) Line with highest passenger density: Colombo-Veyangoda (or ColomboRambukkana) sector has the highest number of passengers using the peak section.

(b) Number of trains required to serve the peak: This depends on the number of passengers in the peak hour in the peak direction. The feasibility study states that this grows by more than 10 times on the KV line (compared with 2016), once the proposed upgrades and electrification is completed. For the other three lines, the baseline figures in 2016 have not been reported.

(c) Share of population in the catchment area taking a daily train ride: Studies report that in 2016, about $5 \%$ of the population in the Divisional Secretariat (DS) divisions served by CSRP take a daily train ride. CSRP studies forecast that this ratio will increase to $21 \%$ by 2025 , once CSRP is implemented.

Considering that the population in the catchment is about $50 \%$ of the population in the Western province, the forecasts imply that about $10.5 \%$ of the entire population of the Western province will take a CSRP train ride every day. 
Colombo Suburban Railway Project:

Review of the Feasibility Study and Proposal for the Way Forward

Table 2: Actual and forecast passengers after implementation of CSRP

\begin{tabular}{|c|c|c|c|c|c|c|c|c|c|}
\hline \multirow[t]{2}{*}{ Line } & \multirow[t]{2}{*}{ Sector } & \multirow{2}{*}{$\begin{array}{l}\text { Sector } \\
\text { length } \\
(\mathrm{km})\end{array}$} & \multicolumn{3}{|c|}{$\begin{array}{l}\text { CSRP: Forecast passengers per } \\
\text { day in both directions in the } \\
\text { peak section }\end{array}$} & \multicolumn{3}{|c|}{$\begin{array}{l}\text { CSRP: Forecast } \\
\text { passengers at peak hour in } \\
\text { peak direction }\end{array}$} & \multirow[t]{2}{*}{ Source } \\
\hline & & & $\begin{array}{c}2016 \\
\text { (actual) }\end{array}$ & 2025 & 2035 & $\begin{array}{l}\text { Actual } \\
(2016)\end{array}$ & 2025 & 2035 & \\
\hline \multirow{2}{*}{ Main } & $\begin{array}{l}\text { FOT- } \\
\text { VGD }\end{array}$ & 37.5 & \multirow{2}{*}{$\underset{\mathrm{a}}{175,400}$} & 539,000 & \multirow{2}{*}{$\begin{array}{l}589,000 \\
501,603\end{array}$} & \multirow{4}{*}{$\begin{array}{l}\text { Not } \\
\text { stated }\end{array}$} & $\begin{array}{l}\text { Not } \\
\text { state } \\
\text { d }\end{array}$ & $\begin{array}{c}\text { Not } \\
\text { stated }\end{array}$ & E \\
\hline & $\begin{array}{l}\text { FOT- } \\
\text { RBK }\end{array}$ & 83.0 & & 419,405 & & & $\begin{array}{c}43,6 \\
18\end{array}$ & 52,167 & D20 \\
\hline Coastal & $\begin{array}{l}\text { FOT- } \\
\text { KTS }\end{array}$ & 41.8 & $\underset{\mathrm{a}}{106,000}$ & 364,200 & 439,198 & & $\begin{array}{c}37,8 \\
77\end{array}$ & 45,677 & D20 \\
\hline PTM & $\begin{array}{l}\text { RGM- } \\
\text { NGB }\end{array}$ & 23.2 & $\begin{array}{c}\text { Not } \\
\text { stated }\end{array}$ & 175,744 & 213,436 & & $\begin{array}{c}18,2 \\
78\end{array}$ & 22,197 & D20 \\
\hline \multirow[t]{2}{*}{ KV } & $\begin{array}{l}\text { MDA- } \\
\text { HMA }\end{array}$ & 26.5 & \multirow{2}{*}{$23,000^{\mathrm{a}}$} & 224,508 & 371,318 & \multirow{2}{*}{$1,638^{\mathrm{a}}$} & $\begin{array}{c}15,9 \\
85\end{array}$ & 26,438 & $\mathrm{E}$ \\
\hline & $\begin{array}{l}\text { MDA- } \\
\text { AVS }\end{array}$ & 61.1 & & 176,969 & 201,662 & & $\begin{array}{c}18,4 \\
05\end{array}$ & 20,973 & D20 \\
\hline
\end{tabular}

\begin{tabular}{|c|c|c|c|c|c|c|}
\hline \multirow{2}{*}{ Line } & \multirow{2}{*}{ Sector } & \multirow{2}{*}{$\begin{array}{l}\text { Sector } \\
\text { length } \\
(\mathrm{km})\end{array}$} & \multicolumn{3}{|c|}{ CSRP: Forecast passenger trips per day } & \multirow[t]{2}{*}{ Source } \\
\hline & & & 2016 (actual) & 2025 & 2035 & \\
\hline Main & FOT-RBK & 83.0 & Not stated & 500,516 & 566,839 & D20 \\
\hline Coastal & FOT-KTS & 41.8 & Not stated & 504,587 & 597,074 & D20 \\
\hline PTM & RGM-NGB & 23.2 & Not stated & 203,023 & 248,311 & $\mathrm{D} 20$ \\
\hline KV & MDA-AVS & 61.1 & Not stated & 273,566 & 365,731 & D19 \\
\hline \multicolumn{2}{|c|}{ Total passenger trips } & 209.1 & 330,902 & $1,481,692$ & $1,777,955$ & D19 \\
\hline \multicolumn{3}{|c|}{$\begin{array}{l}\text { Population in the DS divisions } \\
\text { served by the network }\end{array}$} & $3,067,346^{\mathrm{b}}$ & $3,456,362^{\mathrm{c}}$ & $4,302,189^{c}$ & \\
\hline \multicolumn{3}{|c|}{$\begin{array}{l}\text { Assuming all passengers make return } \\
\text { trips, individuals forecast to be using } \\
\text { CSRP as a share of population in DS } \\
\text { divisions }\end{array}$} & $5 \%$ & $21 \%$ & $21 \%$ & \\
\hline
\end{tabular}

${ }^{a}$ Reported by EGIS only, ${ }^{\mathrm{b}}$ for $2014,{ }^{\mathrm{c}}$ Forecast at a growth rate of $1 \%$ per year. indicatively this population is about $50 \%$ of the entire population in the Western Province.

Source Abbreviations:
E: EGIS, 2018
D19: DHOWA, 2019
D20: DHOWA, 2020

Station Abbreviations:

FOT: Colombo Fort VGD: Veyangoda

RGM: Ragama

PTM: Puttalam
NGB: Negombo

AVS: Avissawella
RBK: Rambukkana

MDA: Maradana
KTS: Kalutara South HMA: Homagama 
In summary, the sector with the highest number of passengers is ColomboVeyangoda, and the second highest is Colombo-Kalutara South. Assuming passenger growth forecasts in the feasibility studies reflect the reality, the passenger trips in CSRP will increase from 330,902 per day in 2016 to $1,777,955$ per day in 2035, a five-fold increase.

By way of a target to be achieved through a major investment in the railway network and rolling stock, a five-fold increase to 1.7 million passenger trips per day appears to present a reasonable target. However, the following aspects require careful consideration to determine the investments which would bring best value for money invested:

(i) severe limitations in capital spending and borrowing,

(ii) uncertainties of government policies that may not facilitate growth in passenger trips, and

(iii) capital intensive nature of railway projects.

Therefore, prioritisation has to be within the framework of constraints.

The KV line admittedly has inadequate capacity which in turn causes a poor passenger turnout. Making the first major investment on Sri Lanka railways after nearly a century, based on assumptions (of passenger numbers on $\mathrm{KV}$ line increasing tenfold) when a ready complement of passengers is already available, using the Panadura-Veyangoda sectors leaving little room for imagination, carries an unwanted risk with public funds.

Therefore, it becomes evident that the move by the Ministry of Transport to prioritise the Colombo-Avissawella line (KV line) has no basis, other than, may be, the fact that the feasibility study on KV line was concluded one year before those of the other lines.

\section{PROJECT OUTLINE}

The CSRP plans to achieve much-delayed upgrading and modernisation of the suburban railway network, in the Western Province. It does not plan to open new rights of way or include major deviations of existing rights of way or tracks. Beyond minimal land acquisition to straighten curves or extend the lengths of station platforms, parking spaces for trains, passenger vehicles and workshops, CSRP will not acquire land to expand or extend the network.

In other words, CSRP aims to provide a more efficient service, using existing rights of way and assets to the best possible extent, investing only on essential upgrades necessary to achieve overall efficiency in terms of energy usage and service provision. 
CSRP, as it is structured now, aims to:

(i) Upgrade and electrify the service in the double tracked sections of the suburban network i.e., Colombo-Rambukkana ${ }^{1}$, Colombo-Kalutara-South ${ }^{2}$ and RagamaNegombo (inclusive of the airport branch) ${ }^{3}$

(ii) Upgrade and electrify the KV line; Colombo-Avissawella ${ }^{4}$

There are a few fundamental features that need to be understood about the existing railways and the upgraded network.

(a) Sharing tracks: Long distance trains (diesel) and electrified trains (suburban) will operate on the same tracks. In a few sections where there will be 4 or more tracks, the suburban service may have two dedicated tracks usually used, but all tracks will be enabled for both electric and diesel services.

(b) Electrification: In electrified sections, power will be supplied by an overhead catenary, a wire suspended above each track. All other operations, including signalling / communications, will be the same for both diesel and electric trains.

(c) Electricity supply: Trains will be supplied with electricity from the national transmission network, but not the local distribution network. When trains brake, part of the energy lost in braking will be converted to electricity and sent back to the grid. A suburban train typically recovers $30 \%$ of the electrical energy used for forward drive, by such "regenerative braking".

(d) Stations: All station platforms will be standardised to $230 \mathrm{~m}$ and to the required height, to accommodate the standard electric multiple unit ${ }^{5}$, enabling swift boarding and alighting.

Accordingly, the feasibility studies have been conducted by DHOWA Consultants, and completed in 2019 for the KV line, and in 2020 for main, coastal and Puttalam lines. The costs, benefits and economic viability, as reported in the feasibility studies are summarised in Table 3.

\footnotetext{
${ }^{1}$ Present plans of CSRP do not include electrification of Veyangoda-Rambukkana section but specifies EMU services to Rambukkana. This requires correction.

${ }^{2}$ Present plans of CSRP are inconsistent about electrification, with some sections stating electrification being limited to Panadura, others stating up to Kalutara South, but EMU services planned up to Kalutara South. This requires correction.

${ }^{3}$ CSRP has not included the station at the airport terminal into the project. A new terminal commenced construction in 2020.

${ }^{4}$ Present CSRP plans propose passengers to Avissawella change to a diesel train at Padukka.

${ }^{5}$ an electric multiple unit or EMU consists of up to 12 cars, with two drive cars and 10 trailer cars. Depending on track curvature specifications, in the context of Sri Lanka, each car will be $15 \mathrm{~m}$ (KV line) or $20 \mathrm{~m}$ long (other lines within CSRP). Passenger information system, centralized door control and air conditioning are expected to be standard features of Sri Lanka's future EMU fleet.
} 
Table 3: Costs and benefits, as assessed in the published feasibility reports

\begin{tabular}{|c|c|c|c|c|c|c|c|}
\hline Line & Sector & $\begin{array}{c}\text { Sector } \\
\text { length } \\
(\mathrm{km})\end{array}$ & $\begin{array}{c}\text { Investmen } \\
\mathrm{t}(\mathrm{USD} \\
\mathrm{mn})\end{array}$ & $\begin{array}{c}\text { Investment } \\
\text { (USD } \\
\text { mn/km of } \\
\text { route) }\end{array}$ & $\begin{array}{c}\text { Economic } \\
\text { benefits in } \\
\text { 2025 (USD } \\
\text { mn per } \\
\text { year) }\end{array}$ & $\begin{array}{c}\text { Economic } \\
\text { simple } \\
\text { payback } \\
\text { period } \\
\text { (years) }\end{array}$ & $\begin{array}{c}\text { Benefit: } \\
\text { cost at a } \\
\text { discount } \\
\text { rate of } \\
9 \%\end{array}$ \\
\hline Main & FOT-RBK & 83.0 & $1,319.7$ & 15.9 & 202.6 & 6.5 & 2.09 \\
\hline Coastal & FOT-KTS & 41.8 & 948.0 & 22.7 & 151.3 & 6.3 & 1.63 \\
\hline PTM & $\begin{array}{c}\text { RGM- } \\
\text { NGB }\end{array}$ & 23.2 & 317.4 & 13.7 & 74.5 & 4.3 & 1.40 \\
\hline KV & $\begin{array}{c}\text { MDA- } \\
\text { AVS }\end{array}$ & 61.1 & $1,424.3$ & 23.3 & 577.4 & $2.5^{\mathrm{a}}$ & $3.50^{\mathrm{a}}$ \\
\hline Total & & 209.1 & $4,009.4$ & 19.2 & & & \\
\hline
\end{tabular}

Sources: Feasibility reports for main, coastal, Puttalam lines (2020) [2] and KV line (2019) [1] ${ }^{\text {a }}$ corrected to account for an arithmetic error in the report

\section{PROJECT ECONOMIC AND FINANCIAL PERFORMANCE}

Table 3 reveals that the KV line design by CSRP displays exceptional economic benefits, causing the economic simple payback period to be extremely attractive and the benefit to cost ratio at a discount rate of $9 \%$ to be 3.5, again a highly attractive index. Projects with such high economic benefits may also be viable for financing by the private sector, especially because the largest share of savings are stated to be in savings in vehicle operating costs. Therefore, the passenger forecast and economic benefits of KV line require more detailed analysis.

Table 4 shows the share of economic benefits for each line from each "type" of economic benefit.

Table 4: Types of economic benefits of each line in CSRP for year 2025

\begin{tabular}{|c|c|c|c|c|c|c|c|c|}
\hline \multirow[b]{2}{*}{ Line } & \multirow[b]{2}{*}{ Sector } & \multirow[b]{2}{*}{$\begin{array}{l}\text { Psgr trips } \\
\text { per daya } \\
\text { in } 2025\end{array}$} & \multicolumn{5}{|c|}{ Economic benefits in 2025 (USD million) } & \multirow{2}{*}{$\begin{array}{c}\text { Economic } \\
\text { benefit }{ }^{\mathrm{a}} \text { in } \\
2025 \text { per } \\
\text { pasgr trip } \\
\text { (USD) }\end{array}$} \\
\hline & & & $\begin{array}{l}\text { Vehicle } \\
\text { operating } \\
\text { costs }\end{array}$ & $\begin{array}{l}\text { Vehicle } \\
\text { operating } \\
\text { time }\end{array}$ & $\begin{array}{c}\text { Accidents } \\
\text { avoided }\end{array}$ & $\begin{array}{c}\text { Emissions } \\
\text { avoided }\end{array}$ & Total & \\
\hline Main & $\begin{array}{l}\text { FOT- } \\
\text { RBK }\end{array}$ & 500,516 & 190.0 & 11.2 & 0.5 & 1.0 & 202.6 & 1.1 \\
\hline Coastal & $\begin{array}{l}\text { FOT- } \\
\text { KTS }\end{array}$ & 504,587 & 143.3 & 7.0 & 0.3 & 0.7 & 151.3 & 0.8 \\
\hline PTM & $\begin{array}{l}\text { RGM- } \\
\text { NGB }\end{array}$ & 203,023 & 51.17 & 17.9 & 2.0 & 3.4 & 74.5 & 1.0 \\
\hline KV & $\begin{array}{l}\text { MDA- } \\
\text { AVS }\end{array}$ & 273,566 & 420.0 & 110.4 & 17.4 & 29.6 & 577.4 & 5.8 \\
\hline
\end{tabular}

Sources: Feasibility reports for main, coastal and Puttalam lines (2020) and KV line (2019)

${ }^{a}$ economic benefit owing to all passengers. Usually, the incremental benefit should be used 
The forecast economic benefits of reduced vehicle operating costs are exceptionally large in the $\mathrm{KV}$ line, indicating that the number of passengers and the type of passengers moving from road to rail, to make-up the forecast 10-fold increase in passenger trips by 2025, are of exceptionally higher economic value. However, the essential requirements such as good and accessible parking facilities near stations, have not been specifically designated or included in project costs of KV line or any other line, but have only been stated as requirements.

Therefore, the passenger forecast and the economic value of cost and time savings, require a deeper evaluation for all lines, especially for the KV line. In case of the financial analysis, the feasibility study for each line concludes, as expected, that the project is not financially viable, meaning that the government should subsidise the project to facilitate its financial sustainability. For example, the government requires to subsidize the KV line to a level of about USD 55 million per year, to enable the $\mathrm{KV}$ line project to be financially viable, and that too, to achieve a poor financial internal rate of return (IRR) of $3 \%$. Table 5 shows the government subsidy proposed to be paid to the CSRP in 2025 and 2035, continuing in increasing quantities throughout its life.

Table 5: Government Subsidy Required to meet CSRP's financial commitments

\begin{tabular}{|l|l|c|c|c|c|c|c|}
\hline \multirow{2}{*}{ Line } & \multirow{2}{*}{ Sector } & \multicolumn{2}{|c|}{$\begin{array}{c}\text { Passenger trips per day in } \\
2025\end{array}$} & \multicolumn{2}{c|}{$\begin{array}{c}\text { Government subsidy } \\
\text { required (USD Mn/year) }\end{array}$} & \multicolumn{2}{c|}{$\begin{array}{c}\text { Subsidy per } \\
\text { passenger trip } \\
\text { (USD) }\end{array}$} \\
\cline { 3 - 8 } & & 2025 & 2035 & 2025 & 2035 & 2025 & 2035 \\
\hline Main & $\begin{array}{l}\text { FOT- } \\
\text { RBK }\end{array}$ & 500,516 & 566,839 & 38.75 & 40.54 & 0.21 & 0.20 \\
\hline Coastal & $\begin{array}{l}\text { FOT- } \\
\text { KTS }\end{array}$ & 504,587 & 597,074 & 32.43 & 33.73 & 0.18 & 0.15 \\
\hline PTM & $\begin{array}{l}\text { RGM- } \\
\text { NGB }\end{array}$ & 203,023 & 248,311 & 12.66 & 13.5 & 0.17 & 0.15 \\
\hline KV & $\begin{array}{l}\text { MDA- } \\
\text { AVS }\end{array}$ & 273,566 & 365,731 & 53.04 & 58.24 & 0.53 & 0.44 \\
\hline All & & $1,481,692$ & $1,777,955$ & 136.88 & 146.01 & 0.25 & 0.22 \\
\hline
\end{tabular}

Sources: Feasibility reports for main, coastal and Puttalam lines (2020) [2] and for the KV line (2019) [1]

Here too, the KV line stands out, indicating that even with a forecast ten-fold increase in passengers, the $\mathrm{KV}$ line requires the highest continuing subsidy from the government per passenger trip. 


\section{RE-ASSESSMENT REQUIRED}

The foregoing summaries of (i) investments and passenger forecasts, (ii) project economic benefits and (iii) subsidy requirements to make the project financially viable (though marginally), point to the need for a deeper review of the project, specifically on it costs and benefits. CSRP, as designed by the Ministry of Transport, concluding with feasibility study reports dated 2019 and 2020:

(a) plans to invest USD 4009 million, on the upgrade and electrification of all the four lines.

(b) forecasts that the ridership will increase from 330,000 (2016) to 1.5 million (2025) passenger trips per day.

(c) on the basis of forecast ridership in the peak hour in the peak direction, determined the number of train sets and the number of services required in the peak hour, and the structure of the line (at-grade or elevated)

As such, CSRP or any of its components will be the largest infrastructure investments ever proposed to be built in Sri Lanka. While increasing the ridership to 1.5 million trips per day is a remarkable target, it would be good to re-examine the project investments.

The project, if implemented as planned at present, will add USD 4000 million to Sri Lanka's national debt. Therefore, project design, unit costs, scope of work and investments require to be investigated deeply and thoroughly by costing specialists, to ensure the project finally provides good value for money in public perception.

This paper therefore, examines only two out of many features of the CSRP that require even deeper analysis:

(i) Number of passengers per hour in the peak direction on KV line

(ii) Cost estimates, considering costs of station construction as an example

\subsection{Number of passengers per hour in the peak direction on KV line}

CSRP design assumes that by 2025 , there will be 15,985 passengers per hour in the peak direction [5]. Subsequently, this has been increased 18,405 (DHOWA, 2019). Considering a ten-car configuration, each car $15 \mathrm{~m}$ long (to enable negotiating sharp curves on KV line; elsewhere in the network, the car length will be $20 \mathrm{~m}$ ), each train can carry 1988 passengers. Accordingly, to serve the forecast peak, the feasibility study has calculated the highest frequency required would be $18,405 / 1988=10$ services per hour or a six-minute headway between trains at peak.

Considering the lower growth scenario used in [5], the more prudent assessment would be $15,985 / 1988=8$ services per peak hour, with the option of using longer train sets of 12 cars each. A twelve-car EMU on KV line would be 12 x $15=180 \mathrm{~m}$ long, and hence can be accommodated on the $230 \mathrm{~m}$ platforms specified for all 
stations. Thus, using a lower, more conservative estimate of 15,985 passengers served in the peak hour in the peak direction using 12 car train sets, the number of services required will reduce to seven, or most likely six, if time-of-use pricing (or similar demand management measure) is implemented. That means a headway of 10 minutes between trains in the peak hour.

CSRP has proposed that since a six-minute headway to provide 10 services in the peak hour will cause congestion at level crossings, the railway line from Colombo to Malapalla (a few $\mathrm{km}$ before Homagama) should be fully elevated. The assumption has been that all level crossings require to be closed for three minutes for a train to pass. The 3-minutes closure duration has been derived through observations of closure durations at a specific railway crossing in the UK [1]. However, such conditions cannot be generalised. With careful management of level crossings assisted by modern equipment, safety systems, smoother road surface and improved signalling, it is possible to limit the closure duration (ringing of warning bell to complete gate opening) to a maximum of 70 seconds. This duration is less than the present closure duration of traffic signals at many road crossings, whereas the remaining 8 minutes and 50 seconds until the next warning bell rings, is at least four times the opening duration of any existing road crossing. Therefore, the physical disturbance to traffic flow will not exceed the disturbance at any existing road crossing managed with traffic signals.

An additional concern of CSRP has been the potential conflict at level crossings near stations. Safety guidelines of Sri Lanka railways require a crossing immediately downstream of a station to be closed before a train approaches a station. With the planned stopping of thirty seconds at a station plus deceleration and acceleration duration, even the most efficient level crossing management near a station is likely to cause a total closure of two minutes and thirty seconds, thus making it longer than the closure duration of many existing traffic signals at road crossings. Sri Lanka Railways have historically used split platforms to overcome this problem, by stopping a train downstream of a level crossing. In this arrangement, up and down platforms will be split, each platform being located after the road crossing. In all stations, all platforms will anyway be interconnected with a passenger underpass, which in this case, can provide exits to road as well as allow roadway pedestrians too, to use the station underpass to safely cross the railway line, as a regular feature. Ramps for wheelchairs too can be arranged within the same underpass. It is obvious that the cost of extending the passenger underpass toward the split platform required at a station with an adjacent road crossing, would only be a fraction of the cost of USD 20 million for a road flyover. Cumulatively, the costs of such underpasses will be a fraction of the cost of elevating the entire KV railway line at a cost of USD 420 million and elevating 14 stations at a cost of USD 70 million. 
However, CSRP has not considered these options, and to overcome the perceived congestion at level crossings, CSRP has proposed line elevation between Colombo and Malapalla, at an additional cost of USD 420 million plus USD 70 million for elevated stations, which is included in the cost estimate stated in Table 3. A closer examination of passenger forecasts and options to relieve congestion at level crossings, would significantly reduce this investment on elevating the lines and stations. The requirement is to provide a unique, cost-efficient solution to each road crossing. Solutions that should have been selectively considered are: (i) closure of the crossing, (ii) combining several crossings together, (iii) split platforms, (iv) shorter railway flyover, (v) road fly-over, (vi) cut and fill for railway, minor road fly-over. However, none of these lower cost options have been evaluated in the CSRP.

Another related concern is the approximately $1.8 \mathrm{~km}$ traverse through the Colombo golf links. Instead of proposing underpasses for golfers to move from the main golf course to the practice links across the railway line, the CSRP design considers it to be an added advantage to elevate the line across the golf course.

\subsection{Excessive cost estimates}

The costs for station construction estimated by CSRP was examined and crosschecked against recent station construction work done in Sri Lanka. While this paper does not attempt to make a detailed BOQ for a station (platforms, buildings and over or underpasses), it is clear that the use of typical costs of Sri Lanka indicate that all the stations can be built for about USD 38 million against USD 190 million estimated by CSRP. Detailed costing or a quantity surveyor's reports have not been provided in CSRP documentation.

Table 6: Potential savings of costs estimated for station construction

\begin{tabular}{|c|c|c|c|c|c|c|c|}
\hline \multirow{3}{*}{ Line } & \multirow{2}{*}{\multicolumn{2}{|c|}{$\begin{array}{l}\text { Number of } \\
\text { stations }\end{array}$}} & \multirow{3}{*}{$\begin{array}{c}\text { Station } \\
\text { construction: } \\
\text { CSRP } \\
\text { estimate } \\
\text { (USD mn) }\end{array}$} & \multicolumn{4}{|c|}{ Typical Sri Lanka costs } \\
\hline & & & & \multicolumn{3}{|c|}{ LKR million } & $\begin{array}{l}\text { USD } \\
\text { million }\end{array}$ \\
\hline & $\begin{array}{c}\text { Mai } \\
\mathrm{n}\end{array}$ & small & & $\begin{array}{c}\text { Main } \\
\text { stations }\end{array}$ & $\begin{array}{c}\text { Small } \\
\text { stations }\end{array}$ & Total & Total \\
\hline Main & 14 & 24 & 57.1 & 1,400 & 1,200 & 2,600 & 13.7 \\
\hline Coastal & 9 & 11 & 48.0 & 900 & 550 & 1,450 & 7.6 \\
\hline PTM & 5 & 8 & 21.5 & 500 & 400 & 900 & 4.7 \\
\hline KV & 12 & 23 & 64.4 & 1,200 & 1,150 & 2,350 & 12.4 \\
\hline Total & 40 & 66 & 190.9 & 4,000 & 3,300 & 7,300 & 38.4 \\
\hline
\end{tabular}

Basis: Main station: $100 \mathrm{Mn}$ LKR

Exchange Rate: 190 LKR/USD

Small station: $50 \mathrm{Mn}$ LKR 
Therefore, large disparities are observed in CSRP cost estimates. Station construction costs were taken as an example to illustrate the potential disparities. A project of this nature and magnitude, would therefore require a more rigorous evaluation by cost estimators and quantity surveyors, as well as cost engineers, to evaluate options and present estimates with justification. The correct approach would be to use unit costs, based on Sri Lanka standard unit costs (for civil works) and internationally published unit costs for others.

\section{A PROPOSED 10-YEAR DEVELOPMENT PLAN FOR EVALUATION}

It is evident that the CSRP, as presently planned, requires numerous improvements. Only a handful of improvements so required, were explained in this paper. While Sri Lanka urgently needs a modern suburban railway network to provide a comfortable ride to existing passengers and to attract more passengers to train, the project requires to be designed with a cost minimisation objective as well. An excessive investment cost estimate is most likely to be rejected by the government or the financiers, including multilateral lending agencies.

A higher cost estimate, coupled with a high passenger demand forecast, can still make a project to appear to be economically viable. Banking large investments on high forecasts that so far do not indicate any trend is dangerous. Cautious assessment and taking small steps at a time, is the usual practice worldwide, when decisions require to be made amidst uncertainty.

Therefore, the present estimate of USD 4000 million investment to raise the daily passenger trips from the present 330,000 to 1.5 million by 2025 , is unlikely to proceed, without major downward revisions to cost estimates. Such downward revisions should be preceded by similar downward revisions to estimates of passenger counts, which in turn would reduce cost estimates by requiring a smaller fleet of trains, avoiding unwanted track elevation to overcome perceived congestion at crossings, and reducing investments on maintenance infrastructure. In other words, the per cent reduction in estimated investments on CSRP will be higher than the per cent reduction in CSRP passenger forecast.

Using international cost databases and costs provided by SLR sources, a "prudent" cost estimate was prepared for the entire CSRP. Table 7 shows the key features of a ten-year plan, along with sequencing of the project, and Table 8 shows these revised cost estimates. The plan reflects a change of priorities presently pursued by CSRP. The first sector to be upgraded and electrified will be Colombo-Veyangoda, closely followed by Colombo-Panadura, especially considering that the maintenance depots to serve all sectors are most likely to be located in Ratmalana. 
Table 7: Indicative Sequence of CSRP Implementation

\begin{tabular}{|c|c|c|c|c|c|c|c|c|c|}
\hline Stage & Sector & Details & 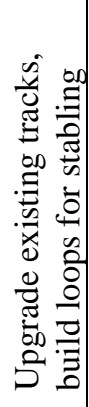 & 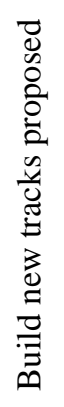 & 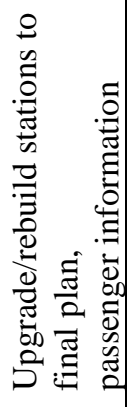 & 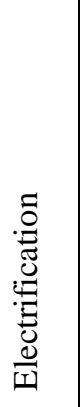 & 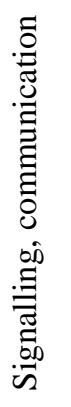 & 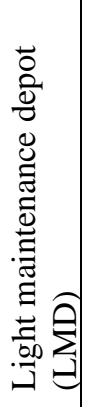 & Comments \\
\hline \multirow[b]{2}{*}{ Stage 1} & $\begin{array}{l}\text { Sector } \\
1\end{array}$ & FOT-VGD & $\mathrm{Y}$ & $\mathrm{Y}$ & Y & Y & Y & $\mathrm{Y}$ & \multirow{2}{*}{$\begin{array}{c}\text { Sector 1or } 2 \text { to } \\
\text { be done first, } \\
\text { to depend on } \\
\text { the location of } \\
\text { the LMD at } \\
\text { Daraluwa or } \\
\text { Ratmalana, } \\
\text { respectively. }\end{array}$} \\
\hline & $\begin{array}{l}\text { Sector } \\
2\end{array}$ & FOT-PND & $\mathrm{Y}$ & $\begin{array}{c}\text { No } \\
\#\end{array}$ & Y & Y & Y & NA & \\
\hline \multirow{2}{*}{ Stage 2} & $\begin{array}{l}\text { Sector } \\
1\end{array}$ & RGM-NGB & Y & NA & $\mathrm{Y}$ & $\mathrm{Y}$ & Y & NA & \\
\hline & $\begin{array}{l}\text { Sector } \\
2\end{array}$ & $\begin{array}{l}\text { Extension } \\
\text { airport }\end{array}$ & Y & $\mathrm{Y}$ & $\mathrm{Y}$ & Y & Y & NA & \\
\hline Stage 3 & - & MMD & NA & NA & NA & NA & NA & NA & $\begin{array}{l}\text { Be alongside } \\
\text { the LMD at } \\
\text { Daraluwa or } \\
\text { Ratmalana }\end{array}$ \\
\hline Stage 4 & $\begin{array}{l}\text { Sector } \\
1\end{array}$ & PND-KTS & Y & NA & $\mathrm{Y}$ & $\mathrm{Y}$ & $\mathrm{Y}$ & NA & \\
\hline \multirow{2}{*}{ Stage 5} & $\begin{array}{l}\text { Sector } \\
1\end{array}$ & MDA-PDK & $\mathrm{Y}+$ & $\mathrm{Y}$ & $\mathrm{Y}$ & $\mathrm{Y}$ & $\mathrm{Y}$ & NA & \\
\hline & $\begin{array}{l}\text { Sector } \\
2\end{array}$ & PDK-AVS & NST & $\mathrm{Y}$ & $\mathrm{Y}$ & $\mathrm{Y}$ & $\mathrm{Y}$ & NA & \\
\hline Stage 6 & Sector & VGD-RBK & Yes & NA & Yes & No & Yes & NA & \\
\hline
\end{tabular}

\# Third track will require beach reclaiming project to be completed.

Y: Yes Y+: Yes and straighten curves NA: not applicable NST: New Single Track LMD: light maintenance depot MMD: Major Maintenance Depot

Station Abbreviations:

FOT: Colombo Fort VGD: Veyangoda RBK: Rambukkana

PND: Panadura

RGM: Ragama

NGB: Negombo

KTS: Kalutara South

PDK: Padukka

AVS: Avissawella

MDA: Maradana 
Table 8: CSRP Implementation: Indicative Parameters and Investment Estimates

\begin{tabular}{|c|c|c|c|c|c|c|c|c|c|}
\hline \multirow[b]{2}{*}{ 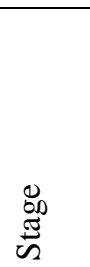 } & \multirow[b]{2}{*}{$\begin{array}{l}\tilde{0} \\
\stackrel{0}{0} \\
\ddot{D}\end{array}$} & \multirow{2}{*}{ 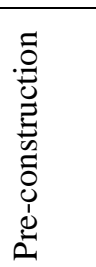 } & \multicolumn{2}{|c|}{ Construction } & \multirow{2}{*}{ 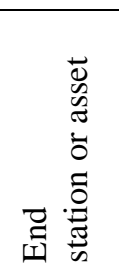 } & \multirow{2}{*}{ 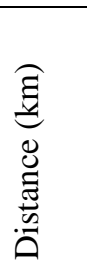 } & \multirow[b]{2}{*}{$\frac{\tilde{0}}{\stackrel{0}{5}}$} & \multirow[b]{2}{*}{$\sum_{i=1}^{\infty}$} & \multirow[b]{2}{*}{ 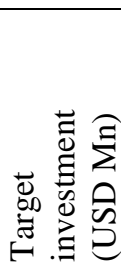 } \\
\hline & & & $\begin{array}{l}\mathscr{0} \\
.0 \\
0 \\
0\end{array}$ & $\frac{\tilde{\theta}}{\tilde{d}}$ & & & & & \\
\hline \multirow[t]{2}{*}{$\begin{array}{l}\text { Stage } \\
1\end{array}$} & $\begin{array}{c}\text { Sector } \\
1\end{array}$ & $\begin{array}{c}2020- \\
2021\end{array}$ & 2022 & 2025 & $\begin{array}{l}\text { VGD, } \\
\text { LMD }\end{array}$ & 36 & 18 & 15 & 460 \\
\hline & $\begin{array}{c}\text { Sector } \\
2\end{array}$ & $\begin{array}{c}2021- \\
2022\end{array}$ & 2023 & 2026 & PND & 29 & 15 & 15 & 380 \\
\hline \multirow[t]{2}{*}{$\begin{array}{l}\text { Stage } \\
2\end{array}$} & $\begin{array}{c}\text { Sector } \\
1\end{array}$ & $\begin{array}{c}2023- \\
2024\end{array}$ & 2025 & 2027 & NGB & 24 & 14 & 10 & 250 \\
\hline & $\begin{array}{c}\text { Sector } \\
2\end{array}$ & $\begin{array}{c}2023- \\
2024\end{array}$ & 2025 & 2027 & Airport & 2 & 1 & - & 10 \\
\hline $\begin{array}{l}\text { Stage } \\
3\end{array}$ & $\begin{array}{c}\text { Sector } \\
1\end{array}$ & $\begin{array}{c}2024- \\
2026\end{array}$ & 2027 & 2028 & KTS & 15 & 5 & - & 80 \\
\hline $\begin{array}{l}\text { Stage } \\
4\end{array}$ & - & $\begin{array}{c}2024- \\
2025\end{array}$ & 2026 & 2027 & MMD & - & - & - & 105 \\
\hline \multirow[t]{2}{*}{$\begin{array}{l}\text { Stage } \\
5\end{array}$} & $\begin{array}{c}\text { Sector } \\
1\end{array}$ & $\begin{array}{c}2021- \\
2026\end{array}$ & 2027 & 2030 & PDK & 35 & 22 & 10 & 480 \\
\hline & $\begin{array}{c}\text { Sector } \\
2\end{array}$ & $\begin{array}{c}2024- \\
2026\end{array}$ & 2028 & 2030 & AVS & 24 & 12 & 4 & 110 \\
\hline $\begin{array}{l}\text { Stage } \\
6\end{array}$ & $\begin{array}{c}\text { Sector } \\
1\end{array}$ & $\begin{array}{c}2027- \\
2028\end{array}$ & 2028 & 2029 & RBK & 47 & 18 & - & 125 \\
\hline \multicolumn{5}{|c|}{ Total CSRP } & & 212 & 105 & 54 & 2,000 \\
\hline
\end{tabular}

Abbreviations:

LMD: Light Maintenance Depot, MMD: Major Maintenance Depot;

EMU: Electric Multiple Unit

Station Abbreviations:

FOT: Colombo Fort VGD: Veyangoda RBK: Rambukkana

PND: Panadura RGM: Ragama NGB: Negombo

KTS: Kalutara South

PDK: Padukka

AVS: Avissawella

MDA: Maradana

Pre-construction: Environmental and other approvals, due diligence by government and financiers, bidding procedure. Long pre-construction durations have been allowed for lines that have substantial relocation and land acquisition, including straightening of curves. 
Figure 2: Indicative Annual Disbursement Schedule for CSRP and Cumulative Investments

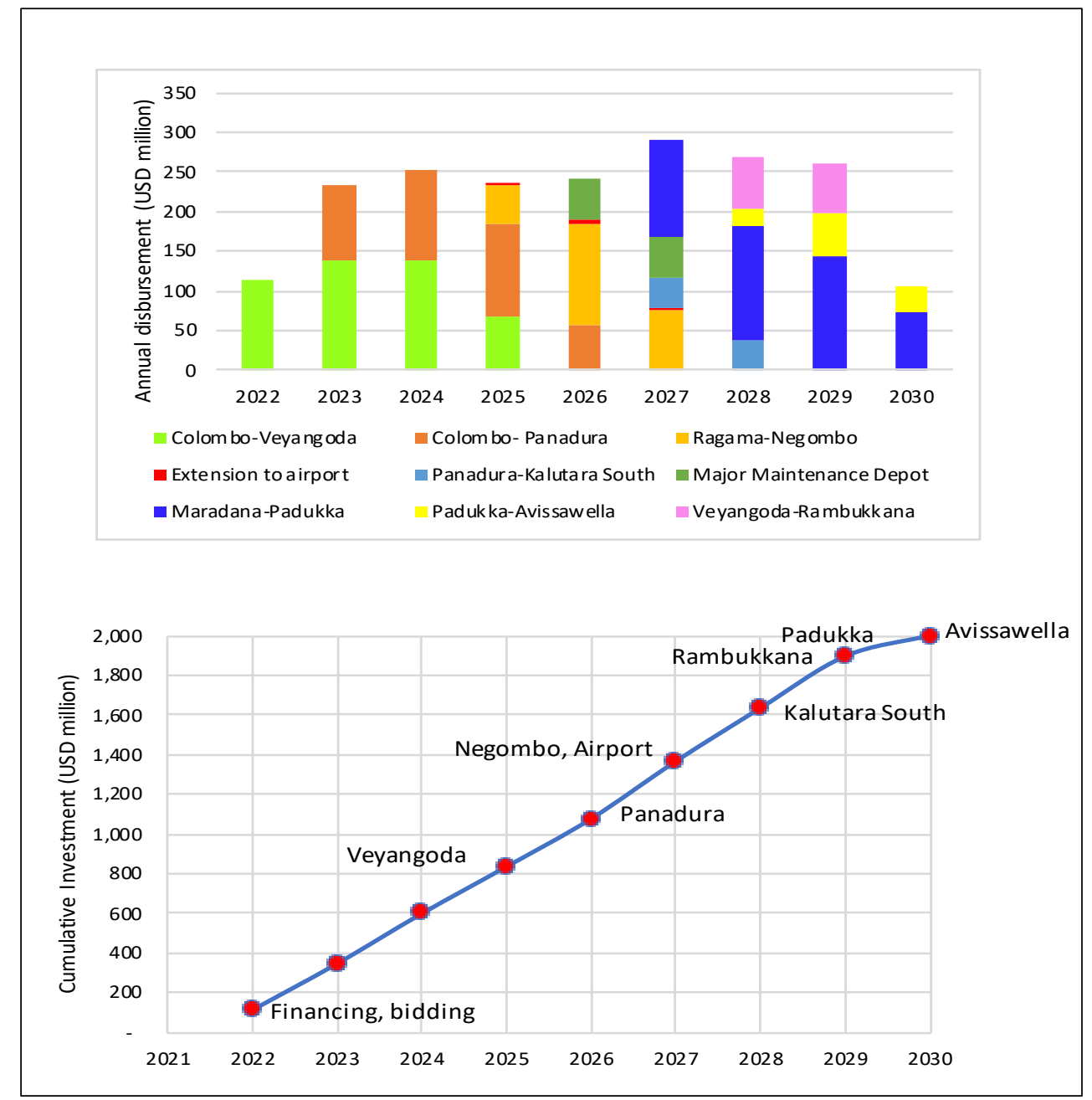

Note:

Sequence of development proposed is on the basis that annual investments would be between USD 110 million and USD 300 million (LKR 20 to 55 billion).

\section{CONCLUSIONS}

The Colombo Suburban Railway Project (CSRP) is presently designed as a USD 4,000 million investment, expecting up to a ten-fold increase in passenger counts. While excessive passenger forecast itself has caused the project costs to increase to such high levels, all subprojects of CSRP require government subsidies. The CSRP, as presently planned, has several issues: incorrect prioritisation of lines to be upgraded, commencing with KV line (with an expectational 10-fold increase in passengers to 273,000) has to be changed to Panadura-Colombo-Veyangoda, which 
already have 330,000 passengers per day. The elevation of KV line, proposed at an additional investment of USD 420 million plus USD 70 million for elevated stations can be reduced by providing a unique solution to each road crossing, along with a realistic passenger forecast, coupled with longer trainsets.

All cost estimates of CSRP require downward revisions and professional assessments by costing specialists, considering transparently applied unit costs, using published information available locally and internationally.

What is presented in this paper is an alternative investment plan and a development sequence, prioritising the sectors with lower investment and higher benefits, eventually upgrading and electrifying all sectors of CSRP by year 2030. This plan too, requires more rigorous re-assessment. However, the present designs and costing of CSRP, if implemented, are most likely to cause a net drain on the national economy rather than providing true economic benefits.

\section{REFERENCES}

[1] Final Feasibility Study Report for KV Line, DOHWA Engineering Co. Ltd, April 11, 2019. www.csrp.lk

[2] Final Feasibility Study Report for Main Line, Coastal Line and Puttalam Line, Volumes I and II, DOHWA Engineering Co. Ltd, August 28, 2020. www.csrp.lk

[3] A Proposal for Railway Electrification, The Institution of Engineers, Sri Lanka, June 2008. https://app.box.com/s/4dgcj6yy3k6g2yo92st8aoudw4x2xf6q

[4] Colombo Suburban Railway Project: Project Preparatory Technical Assistance Final Report, KV line Alternatives Studies, EGIS, December 2017. www.csrp.lk

[5] Colombo Suburban Railway Project: Project Preparatory Technical Assistance Final Report Panadura-Veyangoda Initial Feasibility Volume 1 - Main Report, EGIS, February 2018, www.csrp.lk 